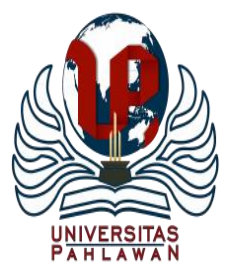

Edukatif : Jurnal Ilmu Pendidikan Volume 3 Nomor 5 Tahun 2021 Halm 2277 - 2286

EDUKATIF: JURNAL ILMU PENDIDIKAN

Research \& Learning in Education

https://edukatif.org/index.php/edukatif/index

\title{
Efektifitas Penggunaan Dana BOS di MTs Swasta pada Masa Pandemi Covid 19
}

\author{
Ridha Albiy ${ }^{1 凶}$, Yahya $^{2}$ \\ Universitas Negeri Padang, Indonesia ${ }^{1,2}$ \\ E-mail : ridha.albiy.1979@ gmail.com ${ }^{1}$, yahyatambunan@ fip.unp.ac.id ${ }^{2}$
}

\begin{abstract}
Abstrak
Bantuan Operasional Madrasah (BOS) program di bidang pendidikan, harus digunakan seefektif mungkin agar tujuan tercapai. Penelitian dilakukan di MTsS Darul Makmur Sungai Cubadak dengan tujuan mengetahui efektivitas penggunaan BOS pada Tahap 2 Tahun 2020 dimana bersamaan dengan masa pandemi covid 19. Jenis dan sumber data yang digunakan data primer dan sekunder. Teknik pengumpulan data wawancara dan dokumentasi, metode analisis deskriptif kualitatif. Hasil penelitian, penggunaan BOS pada Tahap 2 Tahun 2020 efektif. Dalam pandemi Covid 19 di peruntukkan mengantisipasi penyebarannya. Efektivitas terhadap hasil ujian akhir menunjukkan hasil signifikan sehingga memberikan dampak terjadap peningkatan jumlah peserta didik baru pada Tahun pelajaran 2021/2022.
\end{abstract}

Kata Kunci: Efektifitas, Dana BOS, Pandemi Covid 19.

\begin{abstract}
Madrasah Operational Assistance (BOS) programs in the education sector must be used as effectively as possible so that the objectives are achieved. The research was conducted at MTs Darul Makmur Sungai Cubadak. This study aims to determine the effectiveness of using BOS in Phase 2 of 2020 which coincides with the covid 19 pandemic. The types and sources of data used are primary and secondary data. Interview and documentation data collection techniques, qualitative descriptive analysis method. The results of the study, the use of BOS in Phase 2 of 2020 is effective. In the Covid-19 pandemic, it is intended to anticipate its spread. The effectiveness of the final exam results shows significant results so that it has an impact on increasing the number of new students in the 2021/2022 academic year.
\end{abstract}

Keywords: Effectiveness, BOS Fund, Covid 19 pandemic.

Copyright (c) 2021 Ridha Albiy, Yahya

$\triangle$ Corresponding author

Email : ridha.albiy.1979@gmail.com

DOI : https://doi.org/10.31004/edukatif.v3i5.794

ISSN 2656-8063 (Media Cetak)

ISSN 2656-8071 (Media Online)

Edukatif : Jurnal Ilmu Pendidikan Vol 3 No 5 Tahun 2021 p-ISSN 2656-8063 e-ISSN 2656-8071 


\section{PENDAHULUAN}

Pendidikan memiliki pengaruh terhadap perubahan sebuah negara, kemudian mampu meningkatkan kemampuan seluruh warga negara sebagai warga negara yang bertanggung jawab. Melalui siklus perubahan kemajuan dan akan menciptakan siswa semakin terpanggil untuk kemajuan pendidikan, baik secara perorangan meliputi masyarakat luas akan mengantarkannya menjadi insan-insan yang bersaing secara unggul. Sebagian sebab, negara merupakan pelindung orang banyak wajib meningkatan mutu pendidikan harga diri orang banyak semakin meningkat.

Perundangan negara Nomor 20Tahun2003 tentang Sistem Pendidikan Nasional (SNP) menyebutkan bahwa setiap warga negara yang memiliki umur 6.5 sampai 15 tahun, wajib mendapatkan Pendidikan sekolah dasar dan Sekolah Menengah Petama. Dalam pasal 34 pada ayat 3 dalam UUD Republik Indonesia menyatakan bahwa pemerintah dan pemerintah daerah menjamin terlaksananya wajib belajar (atau d singkat menjadi WAJAR paling rendah sekolah dasar SD/SMP tidak boleh meminta anggaran, di ayat 3 juga menegaskan bahwa wajib belajar ini merupakan tangung jawab bangsa yang dilaksanakan oleh pihak sekolah sebagai tanggungan pemerintah baik daerah maupun pusat. Demi terkendalinya dan tercapainya/tertuannya amanah Undang-Undang itu maka pemerintah/pemerintah Daerah wajib melaksanakan pengayoman kualitas pendidikan bagi semua siswa pada tingkatan pembelajaran dasar yaitu di SD/mi dan SMP/MTs dan pesantren setara.

Manfaat dari pendidikan secara gobal dan tertumpu pada peningkatan mutu pendidikan di seluruh bidang, maka pendidikan mampu menjadikan fokus utama bagi bangsa dan negara dan masyarakat sejak Indonesia merdeka. Berbagai cara dan upaya ditempuh, dilakukan untuk meningkatkan pelayanan pendidikan ke depan semakin berkualitas dari tahun ke tahun dan pendidikan dapat dinikmati oleh semua lapisan masyarakat. Upaya untuk meningkatkan kualitas pendidikan tersebut terus menerus dilakukan, mulai dari berbagai pelatihan, kecakapan untuk meningkatkan kualitas guru, perbaikan sarana dan prasarana pendidikan, peningkatan hingga kualitas tata kelola pendidikan di sekolah.

Pendidikan merupakan salah satu aspek terpenting dalam meningkatkan suatu pembangunan Negara. Namun, masih terdapat beberapa masalah terkait dengan penyelenggaraan pendidikan yaitu dalam hal pemerataan, relevansi, efisiensi, dan mutu pendidikan (Dedy Achmad Kurniadi, Linda Setiawati, 2014). Permasalahan klasik yang masih kerap menghinggapi lembaga-lembaga pendidikan, khususnya lembaga pendidikan Islam di negeri ini, adalah problem pemerataan pendidikan serta pembiayaan pendidikan yang dikatakan belum maksimal dalam realisasinya. Hal tersebut berimbas pada hampir semua komponen pendidikan lainnya. Padahal biaya pendidikan merupakan salah satu komponen masukan instrumental (instrumental input) yang sangat penting dalam penyelenggaraan pendidikan di sekolah maupun madrasah. Dalam segala upaya pencapaian tujuan pendidikan, biaya dan pembiayaan pendidikan memiliki peranan yang sangat menentukan. Hampir tidak ada upaya pendidikan yang dapat mengabaikan peranan biaya, sehingga dapat dikatakan bahwa tanpa biaya, proses pendidikan belum bisa berjalan secara maksimal (Munir, 2013).

Tomy Setiawan, menyebutkan bahwa sedikitnya ada empat hal yang harus diperhatikan dalam penggunaan dana BOS yaitu; efisien, efektifitas, transparansi dan akuntabilitas. Pertama, efisien maksudnya adalah dana yang telah didapatkan oleh sekolah/madrasah digunakan dengan sebaik-baiknya dengan memperhatiakan kebutuhan-kebutuhan. Artinya bantuan tersebut jangan sampai salah penggunaan dan tepat sasaran. Kedua, efektifitas maksudnya adalah kelanjutan dari efisien diatas, artinya efektifitas sejauh mana keberhasilan yang dicapai dari hasil keputusan yang pertama. Dan efektifitas ini bisa berarti evaluasi dari program yang yang telah direncanakan sebelumnya. Ketiga, transparansi. Transparansi ini sangat penting, karena jika dari pihak sekolah kurang adanaya transparansi maka dari pihak wali murid juga akan melakukan protes kepada sekolah. Dan ini dimasudkan untuk mengurangi tingkat penyelewengan dari pihak sekolah. Keempat, akuntabilitas maksudnya adalah dalam pencairan dana BOS ini harus bisa dipertanggungjawabkan secara moral kepada Allah swt. serta peraturan perundang-undangan yang berlaku. Jika keempat hal yang 
telah dijelaskan di atas dilakukan dengan baik, maka bantuan BOS dalam penyalurannya akan tepat sasaran. Dan bantuan ini akan lebih bermanfaat bagi orang-orang yang kurang mampu/miskin (Mannuhung, 2020).

Tujuan program bantuan operasinal sekolah adalah untuk meningkatkan kualitas pendidikan dalam upaya menciptakan kualitas sumber daya manusia yang unggul.Untuk meningkatkan sumber daya manusia Indonesia yang unggul, maka diperlukan keikutsertaan tiap warga negara Indonesia secara aktif dalam pendidikan (Bantuan, 2019).

Pelaksanaan program BOS tidak serta merta dilaksanakan berdasarkan keinginan dan kebutuhan sekolah. Untuk itu, pemerintah menerbitkan buku petunjuk teknis penggunaan dan pertanggungjawaban keuangan dana BOS dalam setiap tahunnya. Dalam buku petunjuk tersebut sudah jelas tertulis aturan-aturan pelaksanaan program BOS mulai dari dasar penyelenggaraan program BOS, tujuan BOS, sasaran, pelaksanan program, prosedur pelaksanaan BOS, komponen yang dapat dibiayai dana BOS, larangan penggunaannya, sampai pada monitoring dan laporan pertanggungjawaban sekolah, termasuk juga format-format kegiatan BOS serta pelayanan dan penanganan pengaduan masyarakat terkait pelaksanaan program BOS di sekolah tersebut.

Terkait pengelolaan dana BOS juga sangat tergantung manajemen kepala sekolah. Kepala sekolah dalam tugasnya harus memahami tentang manajemen. Sekurang-kurangnya pihak terkait bisa menyusun perencanaan, mengorganisasikan, memimpin dan mengendalikan anggota, memberdayakan berbagai sumber organisasi dan melakukan evaluasi dalam mencapai tujuan sekolah yang telah ditetapkan (Azhar, 2017).

Sekolah efektif membutuhkan kepemimpinan kepala sekolah untuk mengarahkan dan memotivasi warga sekolah dan semua pihak yang terlibat seperti guru, staf, siswa, orang tua murid, masyarakat agar bersedia bekerja sama untuk mencapai tujuan sekolah yang diharapkan. Kepemimpinan kepala sekolah yang efektif perlu menerapkan strategi kepemimpinan yang tepat yang sesuai dengan konteks yang dihadapi, terutama karakterstik dan kemampuan pengikutnya (Andriani, 2011). Sebuah penelitian oleh (Sadker, D. M., \& Zittleman, 2006) menemukan lima ciri utama sekolah efektif, yang sering disebut dengan five-factor theory (Stenger, 2013). Kelima karakteristik itu adalah (1) kualitas kepemimpinan, (2) harapan yang tinggi pada siswa dan guru, (3) pantauan kinerja dan perkembangan siswa secara terus menerus, (4) adanya tujuan dan arah yang jelas, dan (5) keamanan dan kenyamanan siswa. Kelima faktor ini akan mendorong keberhasilan siswa dan meningkatkan kualitas layanan pendidikan oleh sekolah. Temuan serupa menyatakan bahwa sekolah yang paling effektif mengembangkan kepercayaan yang sangat tinggi diantara stakeholders. Lima kunci sekolah efektif meliputi (1) pedoman pembelajaran yang koheren, (2) sistem yang efektif untuk meningkatkan kapasitas professional guru, (3) kuatnya hubungan orang tua dan sekolah, (4) belajar terpusat siswa, dan (5) kepemimpinan yang kuat (Anrig, n.d.).

Secara etimologi kata efektivitas sebenarnya berasal dari kata "Effect" yang berarti berhasil, dan kata sifatnya adalah "Effective" berarti berhasil, setelah menjadi kata keterangan, efektivitas pengertiannya berubah menjadi berhasil. Jika ditinjau dari segi ekonomi dan manajemen dapat disimak di antaranya pendapat Drukker, sebagaimana dikutip oleh (Soewartoyo, 2007), mendefinisikan efektivitas adalah "suatu ketetapan tindakan atau kesempurnaan (jaminan) hasil suatu pekerjaan." Dengan demikian yang dimaksud dengan keefektifan adalah pencapaian tujuan yang ditetapkan dengan usaha kerja sama.

Robbins (1990: 49) dalam Chairumam (Armia, 2002) mendefinisikan efektivitas organisasi sebagai suatu tingkat untuk dapat merealisasikan tujuannya. Sedangkan menurut Handoko, (1997) dalam Zuliyanti (2005: 26) Efektivitas kerja terdiri dari kata efektivitas dan kerja. Efektivitas merupakan kemampuan untuk memilih tujuan atau peralatan yang tepat untuk pencapaian tujuan yang ditetapkan.

Berdasarkan dari beberapa pendapat diatas jelas bahwa, efektifitas menggambarkan suatu pengertian terhadap suatu keadaan, dimana metode-metode yang ditemukan atau kesempurnaan hasil suatu pekerjaan yang diinginkan. Seperti halnya dalam penggunaan dana BOS disekolah, termasuk kategori efektif apabila dana tersebut tepat sarasan dan didayagubakan sesuai dengan aturan dan ketentuan yang berlaku. 
Disamping itu wabah COVID-19 mendesak dilaksanakannya pendidikan jarak jauh hampir yang belum pernah dilakukan secara serempak sebelumnya (Sun et al., 2020) bagi semua elemen pendidikan, yakni peserta didik, guru hingga orangtua. Mengingat pada masa pandemic, waktu, lokasi dan jarak menjadi permasalahan besar saat ini (Kusuma, n.d.). Sehingga pembelajaran jarak jauh menjadi solusi untuk mengatasi kesulitan dalam melaksanakan pembelajaran secara tatap muka langsung. Ini memberikan tantangan kepada semua elemen dan jenjang pendidikan untuk mempertahankan kelas tetap aktif meskipun sekolah telah ditutup.

Krisis kesehatan yang diakibatkan oleh wabah COVID-19 telah mempelopori pembelajaran online secara serempak. Tsunami pembelajaran online telah terjadi hampir diseluruh dunia selama pandemi COVID19 (Goldschmidt \& Msn, 2020). Guru dan pendidik sebagai elemen penting dalam pengajaran diharuskan melakukan migrasi besar-besaran yang belum pernah terjadi sebelumya dari pendidikan tatap muka tradisional ke pendidikan online atau pendidikan jarak jauh (Bao, 2020). Ini didukung dengan perkembangan teknologi yang tidak terbatas pada revolusi industri 4.0 saat ini. Pembelajaran online secara efektif untuk melaksanakan pembelajaran meskipun pendidik dan peserta didik berada di tempat yang berbeda (Verawardina, U., Asnur, L., Lubis, A. L., \& Hendriyani, 2020). Ini mampu menyelesaikan permasalahan keterlambatan peserta didik untuk memperoleh ilmu pengetahuan. Pandemic COVID-19 secara tiba-tiba mengharuskan elemen pendidikan untuk mempertahankan pembelajaran secara online. Kondisi saat ini mendesak untuk melakukan inovasi dan adaptasi terkait pemanfaatan teknologi yang tersedia untuk mendukung proses pembelajaran (Ahmed, S., Shehata, M., \& Hassanien, n.d.). Praktiknya mengharuskan pendidik maupun peserta didik untuk berinteraksi dan melakukan transfer pengetahuan secara online. Pembelajaran online dapat memanfaatkan platform berupa aplikasi, website, jejaring sosial maupun learning managemen sistem (Gunawan \& Fathoroni, 2020). Berbagai platform tersebut dapat dimanfaatkan untuk mendukung transfer pengetahuan yang didukung berbagai teknik diskusi dan lainnya.

Berkaitan dengan hal tersebut diatas maka penelitian ini difokuskan pada afektifitas penggunaan dana BOS di MTsS darul mamkur Sungai Cubadak Kabupaten Agam tahap 2 Tahun 2020, dimana pelaksanaan kegiatan ini mulai dari bulan Juni sampai dengan Desember Tahun 2020 bertepatan dengan berlangsungnya pandemic covid 19.

\section{METODE PENELITIAN}

Penelitian ini dilakukan pada MTsS Darul Makmur Sungai Cubadak Kabupaten Agam, dimana madrasah ini merupakan tempat penulis bekerja. Dengan keadaan ini diharapkan data dan informasi yang diharapkan lebih akurat dan real. Di samping itu juga karena lebih mudah jangkauan informasi, ketersediaan tenaga dan waktu serta efisiensi biaya. Sedangkan informan dari penelitian ini adalah bendahara BOS dan pihak-pihak terkait yang berhubungan dengan proses pembiayaan di madrasah.

Jenis data yang digunakan adalah data primer dan sekunder. Data primer, yaitu data yang diperoleh dari sumber utama baik individu maupun kelompok yang diperoleh. Data primer dalam penelitian ini diperoleh melalui wawancara. Sedangkan data sekunder, yaitu yang telah diolah dan disajikan oleh pihak lain. Data sekunder dalam penelitian ini adalah data yang berupa laporan administrasi atau dokumen yang berkaitan dengan pelaksanaan program bantuan dana bantuan operasional madrasah pada MTsS darul mamkur Sungai Cubadak Kabupaten Agam.

Teknik pengumpulan data adalah melalui wawancara. Dimaksudkan untuk memperoleh data kualitatif serta beberapa keterangan atau informasi dari informan. Wawancara mendalam ini dilakukan terhadap narasumber yang dianggap memiliki pengetahuan yang memadai tentang suatu persoalan atau fenomena pelaksanaan dana BOS yang diamati. Disamping itu juga dengan dokumentasi, yaitu pengambilan atau penggunaan dokumen resmi dari lembaga/organisasi yang telah melaksanakan program dana Bantuan 
Operasiona Madrasah (BOS) selaku pihak yang telah menerima dana bantuan BOS sebagai bukti-bukti fisik dari kegiatan yang telah diselenggarakan.

Metode analisis data yang digunakan dalam penelitian ini adalah analisis deskriptif kualitatif, yaitu merupakan metode yang dilakukan dengan cara mengumpulkan, mengolah, dan menyajikan data serta membandingkan antara teori dan kenyataan yang akan dijumpai pada objek penelitian. Untuk mengukur apakah efektivitas penggunaan Dana BOS pada MTsS darul mamkur Sungai Cubadak Kabupaten Agam dapat dilihat dari ketepatan atau kesesuaian antara penggunaan dana BOS dengan petunjuk pelaksana.

\section{HASIL DAN PEMBAHASAN PENELITIAN}

Sekolah merupakan sebuah institusi negara yang memiliki peran paling penting di negara ini. Sekolah menjadi tempat untuk menempa generasi-generasi bangsa yang diharapkan di kemudian hari akan membawa perubahan ke arah yang lebih baik untuk negara ini. Kebijakan wajib belajar 9 (Sembilan tahun) yang dikeluarkan pemerintah menjadi bukti akan adanya komitmen yang kuat dari pemerintah untuk memajukan bangsa ini melalui sekolah. Bantuan Operasional Sekolah (BOS) adalah program pemerintah yang pada dasarnya adalah untuk penyediaan pendanaan biaya operasi nonpersonalia bagi satu_an pendidikan dasar sebagai pelaksana program wajib belajar. Program Bantuan Operasional sekolah (BOS) yang dimulai sejak bulan juli 2005, telah berperan secara signifikan dalam percepatan pencapaian program wajib belajar 9 tahun. Oleh karea itu, mulai tahun 2009 telah melakukan perubahan tujuan, pendekatan, dan orientasi program BOS, dari perluasan akses menuju peningkatan kualitas. Sebagaimana diketahui bahwa dana BOS bertujuan untuk meringankan beban orang tua dalam pendidikan, terlebih bagi orang yang tidak mampu. Jika di sekolah terdapat siswa miskin, maka pihak sekolah bisa mengalokasikan dana BOS untuk membantu siswa yang miskin tersebut. Penggunaan dana BOS di sekolah harus didasarkan pada kesepakatan dan keputusan bersama antara Tim Manajemen BOS Sekolah, Dewan Guru dan Komite Sekolah.

Hasil kesepakatan diatas harus dituangkan secara tertulis dalam bentuk berita acara rapat dan ditandatangani oleh peserta rapat. Kesepakatan penggunaan dana BOS harus didasarkan skala prioritas kebutuhan sekolah, khususnya untuk membantu mempercepat pemenuhan standar pelayanan minimal dan/atau standar nasional pendidikan.

Adanya BOS bertujuan untuk meringankan beban masyarakat terhadap pembiayaan pendidikan. Membebaskan pungutan bagi seluruh siswa miskin baik di satuan pendidikan negeri maupun swasta, dengan harapan agar siswa mendapatkan pendidikan wajib belajar 9 tahun yang bermutu. Tujuan lainnya untuk membebaskan biaya pendidikan bagi siswa miskin/tidak mampu dan meringankan bagi siswa yang lain, agar mereka memperoleh layanan pendidikan yang layak (Maria \& Padang, 2021).

Cakupan dana BOS bagi anak didik keluarga miskin berdasarkan kajian hasil data siswa yang telah disusun oleh madrasah, RAPBM dan laporan pertanggung jawaban pelaksanaan MTsS Darul Makmur Sungai Cubadak. Pengajuan dana BOS untuk madrasah swasta dilaksanakan dalam 2 tahap selama 1 tahun. Tahap 1 untuk bulan Januari sampai dengan Juni 2020, dan tahap 2 bulan Juli sampai dengan Desember 2020. Tercatat pada tahap 2 Tahun 2020. Tercata sebanyak 275 orang siswa/I pada tahap 2 tahun 2020 yang akan mendapatkan subsidi pendidikan sebesar Rp. 1.100.000,- pertahunnya dengan alokasi dana berjumlah sebesar Rp. 116.000 rupiah dengan rincian sebagai berikut. Namun karna adanya pandemi covid ini maka dana BOS yang semula di alokasikan untuk bantuan pendidikan kepada anak didik dari keluarga miskin di potong sebesera Rp.100.000,- untuk dialihkan ke dana Covid 19. Hal ini senada denga napa yang disamikan oleh Menteri Agama RI bahwa penghematan Dana BOS tersebut dilakukan sebagai kontruksi anggaran program pendidikan Islam kemenag dan mencermati pembelajaran jarak jauh (PJJ) yang tidak berjalan efektif selama tiga bulan ini (Sari, 2020). Dibawah ini dapat dilihat rincian penerimaan dana BOS Tahap 2 Tahun 2020. 
Tabel 1. Penerimaan Dana BOS Tahap 2 Tahun 2020

\begin{tabular}{cccc}
\hline No & Uraian & Indeks Persiswa & Jumlah \\
\hline 1. 275 peserta Didik & Rp. 450.000 & Rp. 123.750.000 \\
\hline
\end{tabular}

Dapat juga di tampilkan dalam bentuk diagram berikut :

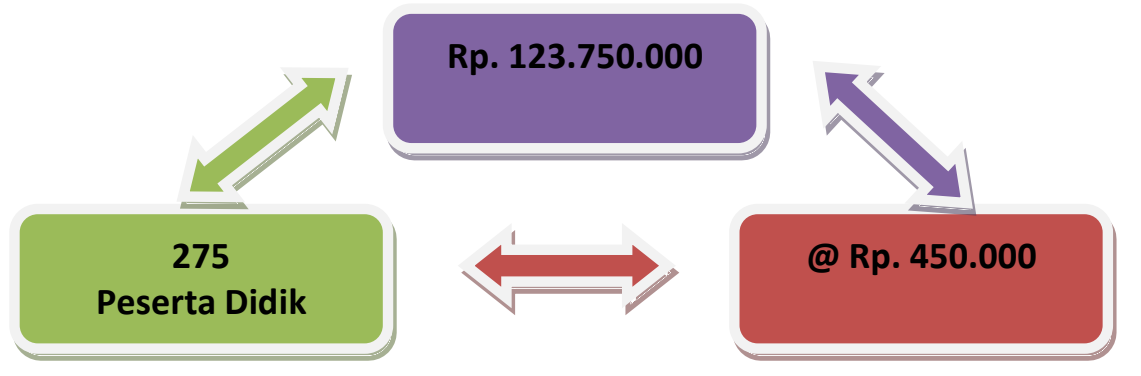

Diagram 1 Penerimaan Dana Bos Tahap 2 Tahun 2020 MTsS Darul Makmur Sungai Cubadak

Adapun mekanisme pencairan dana BOS di madrasah swasta dilakukan oleh Kanwil Kementrian Agama Propinsi Sumatera Barat atau Kantor Kementrian Agam Kabupaten Kota melalui mekanisme pembayaran langsung (LS) ke rekening madrasah penerima bantuan operasional tersebut. Dana BOS madrasah swasta tersebut dialokasikan pada DIPA Kantor Wilayah Kementrian Agama Provinsi, maka Kuasa Pengguna Anggaran atas DIPA dimaksud dapat menetapkan Pejabat pembuat Komitmen (PPK) khusus untuk pencairan dana lebih dari 1 (satu) orang sesuai kebutuhan pada Kanwil Kementerian Agama Propinsi atau Kantor Kemnetrian Agama Kabupaten Kota/melalui surat keputusan (Juknis BOP RA dan BOS Madrasah 20020.Pdf, n.d.).

Selanjutnya dana BOS yang sudah dialokasikan untuk masing-masing madrasah tersebut diterima dalam 2 tahap. Pada tahap 1 di bayarkan sebesar $50 \%$ paling lambat minggu ke 3 bulan maret 2020. Dan untuk tahap 2 dinayarkan 50\% lagi paling lambat minggu ke 3 bulan September dengan syarat dan ketentuan yang telah di tetapkan salah satunya adalah RKAM (Rencana Kerja dan Anggran Madrasah) yang bertujuan untuk merancang dan melihat apakah kebutuhan yang diperlukan oleh madrasah untuk tahap tersebut.

Setelah dana BOS tersebut diajukan dan di cairkan, kemudian madrasah melaksanakan kegiatan pembelajaan dana BOS sesuai dengan juknis yang telah ditetapkan. Pada bualn terakhir setiap tahap dilakukan pembuatan laporan penggunaan dana BOS tersebut. Berdasarkan laporan Pertanggungjawaban Dana BOS Tahap 2 Tahun 2020 MTsS Darul Makmur Sungai Cubadak dapat disajikan data berikut:

Tabel 2. Realisasi Penggunaan dana BOS Tahap 2 Tahun 2020 di MTsS Darul Makmur Sungai Cubadak

\begin{tabular}{|c|c|c|c|c|}
\hline No & Komponen & Realisasi & Persentase & Ket \\
\hline 1 & Kegiatan Pembelajaran & $6,480,000$ & 5.24 & \\
\hline 2 & Kegiatan ekstrakurikuler & $1,950,000$ & 1.58 & \\
\hline 3 & $\begin{array}{l}\text { kegiatan Evaluasi Pembelajaran dan } \\
\text { Ekstrakurikuler }\end{array}$ & $8,499,100$ & 6.87 & \\
\hline 4 & Kegiatan Pengembangan Potensi Siswa & $2,950,000$ & 2.38 & \\
\hline 5 & $\begin{array}{l}\text { Pengembangan keprofesian Guru dan } \\
\text { tenaga Kependidikan }\end{array}$ & $2,495,000$ & 2.02 & \\
\hline 6 & Honor Rutin & $56,087,400$ & 45.32 & \\
\hline
\end{tabular}


2283 Efektifitas Penggunaan Dana BOS di MTs Swasta pada Masa Pandemi Covid 19 - Ridha Albiy, Yahya DOI: https://doi.org/10.31004/edukatif.v3i5.794

\begin{tabular}{|c|c|c|c|c|}
\hline No & Komponen & Realisasi & Persentase & Ket \\
\hline 7 & Pemeliharaan sarana dan prasarana & $7,754,750$ & 6.27 & \\
\hline 8 & Pengembangan perpustakaan & $1,250,000$ & 1.01 & \\
\hline 9 & Kegiatan penerimaan peserta didik baru & - & 0.00 & \\
\hline 10 & Kegiatan Matsama & $2,625,000$ & 2.12 & \\
\hline 11 & Pengelolaan madrasah & $16,776,250$ & 13.56 & \\
\hline 12 & Langganan Daya dan Jasa & $3,026,500$ & 2.45 & \\
\hline 13 & $\begin{array}{l}\text { Pembelian/perawatan alat multi media } \\
\text { pembelajaran (termasuk penunjang } \\
\text { UABK/UAMBNBK) }\end{array}$ & $7,610,000$ & 6.15 & \\
\hline 14 & $\begin{array}{l}\text { Biaya lainnya jika seluruh komponen } 1 \mathrm{s.d} \\
13 \text { telah terpenuhi pendanaanya dari BOS }\end{array}$ & $6,246,000$ & 5.05 & \\
\hline & Jumlah & $123,750,000$ & 100.00 & \\
\hline
\end{tabular}

Sumber : MTsS Darul Makmur Sungai cubadak, 2021

Data tersebut juga bisa ditampilkan dalam diagram berikut:

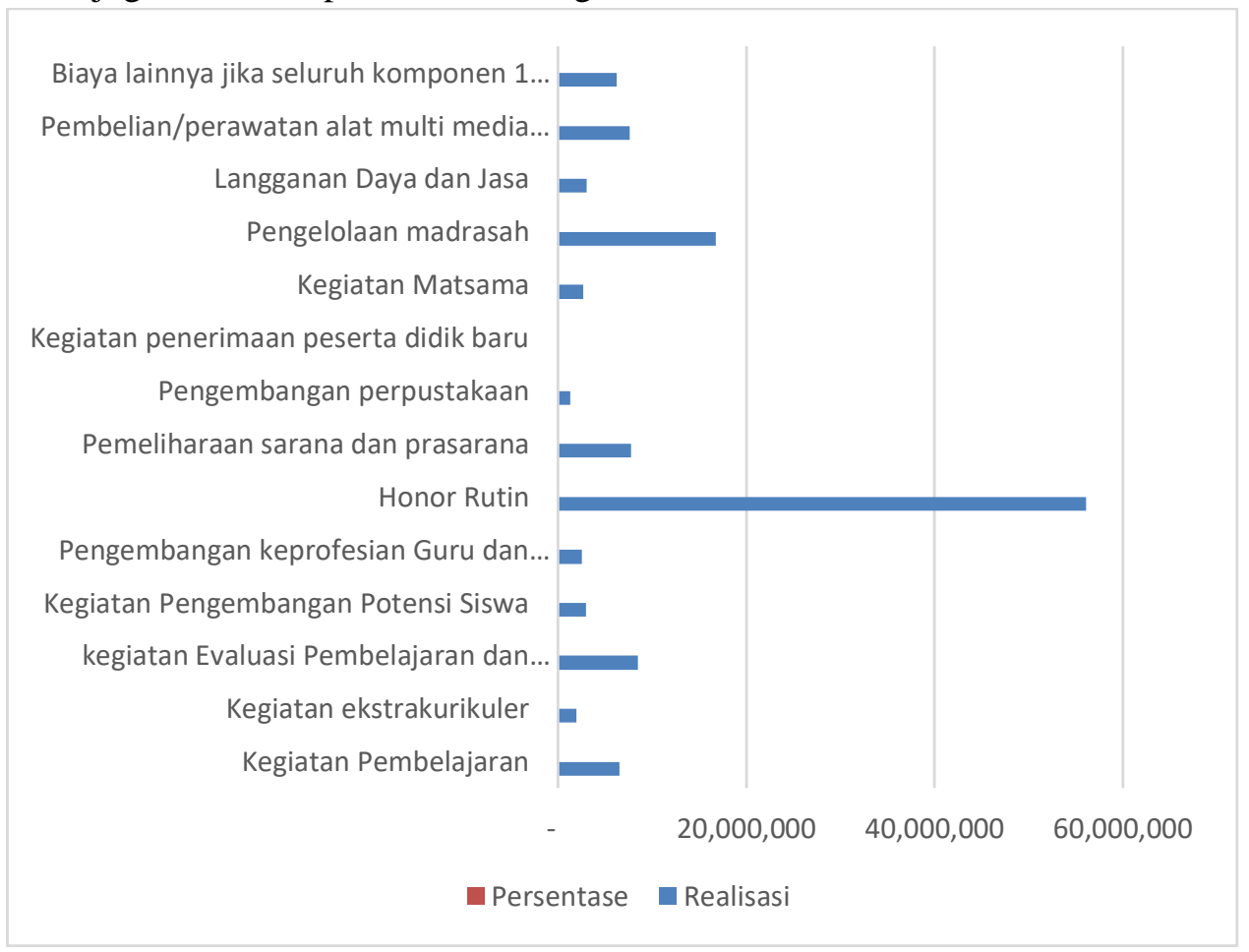

Diagram 2 Realisasi Anggran dana BOS Tahap 2 MTsS Darul Makmur Sungai Cubadak

Dari tabel 3 diatas dapat diketahui bahwa dari anggaran sebesar Rp. 123.750.000, 5.4\% atau sekitar Rp. 6.480.000,- digunakan untuk kegiatan pembelajaran yang meliputi pembelian atau penggantian alat peraga pendidikan yang diperlukan madrasah untuk emmenuhi SNP serta mendukung penyelenggaraan pembelajaran 
aktif, kreatif, efektif dan menyenangkan atau contectual teaching and learning. Karna kondisi saat itu adalah dalam pandemic covid 19 dan semua siswa belajar dalam kondisi daring, maka dana ini juga di alokasikan pada pengembangan media pembelajaran berbasis teknologi.

Kegiatan ekstrakurikuler pada Tahap 2 Tahun 2020 ini mengalami penurunan kegiatan disebabkan pandemi covid. Dari beberapa kegiatan ekstrakurikuler yang dirancang dan dilaksanakan oleh madrasah hanya menyerap dana sebesar $1.58 \%$ atau sekitar Rp. 1.950.000,-. Untuk kegiatan evaluasi pembelajaran dan ekstrakurikuler di madrasah telah menyerap biaya sebesar 6.87\% taua sekitar Rp.8.499.100,-. Kegiatan ini meliputi pelaksanaan ulangan tengah semester dan ulangan akhir semester I TP 2020/2021 yang dilaksanakan secara daring.

Kegiatan pengembangan potensi siswa menyrap dana sebesar 2.38\% atau sekitar Rp. 2.950.000,-. Dana ini dialokasikan pada persispan siswa dalam mengkuti kegiatan Kompetisi Sain Madrasah (KSM) secara ON Line. Namun persiapan yang dilaksanakan sudah semenjak beberapa waktu sebelumnya. Pengembangan keprofesian guru dan tenaga kependidikan, serta pengembangan manajemen madrasah dalam realisasinya sebesar 2,02\% atau sekitar Rp. 2.495.000,-. Dana ini meloputi kegiatan yang dikuti oleh gur dalam rangka peningkatan kompetensi guru dalam kegiatan MGMP serta bimtek lainnya. Kegiatan ini juga di ikuti oleh tenaga kependidikan.

Penyerapan dana yang terbesarvdalam realisasi Dana BOS ini adalah pembayaran honor rutin. Dimana dari $100 \%$ dana BOS yang tersedia di tahap 2 ini $42.35 \%$ atau sekitar Rp. 56.087.400,- digunakan untuk pembayar honorarium pendidik dan tenaga kependidikan. Alokasi ini melebihi dari batas yang ditetapkan dalam juknis yaitu sebesar 20\%. Namun untuk madrasah swasta ada sedikit kelonggaran dalam pengalokasian dana BOS, dimana apabila tidak ada lagi sumber dana yang lain untuk pembiayan hinor rutin, boleh dialokasikan oleh Dana BOS.

MTsS darul Makmur Sungai Cubadak, merupakan lembaga pendidikan swasta yang bernaung dibawah Pondok Pesantren Darul Makmur Sungai Cubadak. Dalam penunjang biaya operasionalnya. Pondok Pesantren tetap mengaharapkan infak bulanan dari orang tua siswa. dan itu hanya digun akan untuk pembiayaan honor rutin tenaga pengajar pesantren dan penambah biaya operasional lainnya yang tidak terpenuhi oleh dana BOS.

Untuk pemeliharaan sarana dan oprasarana madrasah dana yang terserap adalah sebesar $6,27 \%$ atau sekitar RP. 7.754.750,-. Dana tersebut dialkoasikan untuk pembelian beberapa buah meja guru dan pemeliharaan ringan beberapa sarana madrasah. Untuk pengembangan perpustakaan hanya $1.01 \%$ atau sekitar Rp. 1.250.000,-. Untuk tahap 2 ini tidak ada pengalokasian dana untuk penerimaan peserta didik baru, namun untuk kegiatan matsama sebesar $2.12 \%$ atau Rp. 2.625.000,--

Untuk kegiatan pengembangan madrasah yang meliputi pembelian bahan habis pakai dalam mendukung kegiatan pembelajaran, administrasi dan layanan umum, dan tata usaha dan perkantoran yang melipiuti konsumsi, fotocopy, dokumentasi ATK, dan penggandaan laporan sebesar 13, 56\% atau Rp. 16.776.250,-. Dana ini juga di alokasikan untuk penyusunan RKAM, penyampaian laporan hasil belajar melalui aplokasi rapor digital dan pendataan memalui EMIS serta pembayaran honor unyuk operator aplikasi di madrasah.

Langganan daya dan jasa mengahbiskan dana sebesar 2.45\% atau sekitar Rp. 3.026.500,-. Dana ini melipiuti pembayaran langgana koran dan speedy. Untuk pembelian/perawatan alat multi media pembelajaran (termasuk penunjang UNBK/UAMBN-BK) menghaboskan dana sekitar 6.15\% atau sekitar Rp. 7.610.000,-. Dana ini dialokasikan untu pengadaan Lapotop penunjang kegiatan E-Learning Madrasah. Adapun biaya lainnya jika seluruh komponen $1 \mathrm{~s} / \mathrm{d} 13$ telah terpenuhi pendanaannya oleh BOS adalah sebesar 5.05\% atau sebesar Rp. 6.246.000,-. Dana ini dilakokasikan untuk pengadaan sarana dan prasarana covid 19 seperti pengadaan tem;pat cuci tangan, masker, handsanitizer, alat penyemprotan dsb.

Aturan penyelenggaraan program BOS, secara tegas ditentukan di dalam juknis yang dikeluarkan setiap tahun. Hasil kajian memperlihatkan bahwa dalam pelaksanaanya BOS cenderung diperlakukan sebagai subsidi umum untuk membiayai kegiatan operasional madrasah dan semua murid menerima manfaat program BOS. 
Secara konseptual, madrasah memegang kunci dalam penentuan penggunaan BOS termasuk dalam kebijakan pemberian bantuan khusus untuk siswa miskin. Berdasarkan ketentuan (panduan BOS), dana BOS dikelola oleh Kepala Madrasah, Guru/tenaga administrasi. Uang dikirim langsung ke nomor rekening madrasah oleh Madrasah boleh menggunakan BOS tersebut dengan berbagai jenis kegiatan berdasarkan RAPBM (Rencana Anggaran Pendapatan dan Belanja Madrasah).

Efektivitas penggunaan dana BOS di MTsS Darul Makmur Sungai Cubadak dapat dilihat dari ketepatan atau kesesuaian antara penggunaan dana BOS dengan petunjuk pelaksanan. Dilihat secara keseluruhan, penggunaan dana BOS cukup efektif. Dilihat dari dampak BOS itu sendiri terhadap hasil Ujian Akhir Madrasah cukup menunjukkan hasil yang signifikan. Kemudian untuk penerimaan siswa baru juga mengalami peningkatan. Pemberian bantuan dana BOS diharapkan dapat memberikan dampak nyata bagi dunia pendidikan. Dampak tersebut dapat dilihat dari berbagai macam/hal, diantaranya dapat dilihat dari efektivitas penggunaan dana BOS yang digunakan untuk Keperluan siswa, apalagi dalam situasi Pandemi Covid 19, dengan adanya dana BOS juga dialokasikan untuk pembelian thermogan, masker, fielshild dan handsanatizer bagi seluruh siswa juga untuk melengkapai fasilitas dalam rangka memutus rantai Covid 19, seperti melengkapi sarana mencuci tangan dengan air yang mengalir lengkap dengan sabun dan tisu. Di samping itu alokasi dana BOS pada Tahap 2 Tahun 2020 ini juga digunakan untuk pemeblian lapotop untuk penunjang pembelajaran jarak jauh, sehingga dengan adanya E Learning ini dapat meningkat semangat dan kinerja guru dalam pembelajaran di era covid 19.

Dalam pengelolaan dana BOS di MTsS darul Makmur Sungai cubadak, tentunya tidak terlpas dari manajemen yang tepat dari kepala madrasah. Sebab bila hanya mengandalkan dari dana BOS saja sudah tentu ada kekurangan di sana sini. Namun berkat kerjasama dan kolaborasi denga Pondok Pesantren sehingga semua pembiayaan yang ditimbulkan dari pelaksanaan pendidikan ini diselesaikan secara bersama, sehingga proses belajar mengajar bisa berlangsung dengan baik tanpa ada kendala, dan dengn berjalannya pembelajarn dengan baik berdampak pada hasil ujian akhir dan peningkatan jumlah siswa pada Tahun 2021/2022 ini.

\section{KESIMPULAN}

Berdasarkan penelitian yang telah peneliti lakukan, penggunaan dana BOS pada Tahap 2 Tahun 2020 di MTsS darul Makmur Sungai Cubadak sudah berjalan efektif sesuai dengan yang direncanakan dan dibutuhkan serta sesuai dengan peraturan perundang-undangan yang berlaku. Sehingga dapat bermanfaat untuk peserta didik seperti pembelian lapotop untuk pendukung kegiatan E-Learning yang dapat membantu proses belajar jarak jauh. Apalagi di suasana pandemik covid 19 saat ini juga memerlukan akan kebutuhan berbagai alat pencegahan penyebaran virus corona. Selain itu tentunya juga bermanfaat bagi madrasah. Tentunya semua itu tidak telepas dari manajemen yang tepat oleh leader yang mumpuni serta tenaga pengolah yang profesional dengan aspek kerjasama dan sama-sama bekerja oleh seluruh stakeholder dibawah handle kepemimpinan yang selalu siap melayani berbagai pihak di MTsS Darul Makmur Sungai Cubadak. Kemudian dilihat dari dampak BOS itu sendiri terhadap hasil Ujian Akhir Madrasah menunjukkan hasil peningkatan yang cukup signifikan, termasuk lebih meningkatnya jumlah peserta didik yang mendaftar di MTsS Darul Makmur Sungai Cubadak.

\section{DAFTAR PUSTAKA}

Ahmed, S., Shehata, M., \& Hassanien, M. (N.D.). Emerging Faculty Needs For Enhancing Student Engagement On A Virtual Platform. Mededpublish. Https://Doi.Org/Https://Doi.Org/Https://Doi.Org/10.15694/Mep.2020.000075.1

Andriani, D. E. (2011). Strategi Kepemimpinan Kepala Sekolah Dalam Upaya. Jurnal Manajemen Pendidikan, 01, 51-62.

Anrig, G. (N.D.). Beyond The Education Wars. 
2286 Efektifitas Penggunaan Dana BOS di MTs Swasta pada Masa Pandemi Covid 19 - Ridha Albiy, Yahya DOI: https://doi.org/10.31004/edukatif.v3i5.794

Armia, C. (2002). Pengaruh Budaya Terhadap Efektivitas Organisasi : Dimensi Budaya Hofstede. 6(1), 103117.

Azhar, S. (2017). Kepemimpinan Kepala Sekolah Efektif ( Perspektif Pendidikan Islam ) Leadership Of The Head Of Effective School ( Islamic Education Perspective ). 4(1), 20-29.

Bantuan, D. (2019). Efektivitas Pengelolaan Dana Bantuan Operasional Sekolah ( BOS ) Dalam Meningkatkan Sarana Dan Prasarana Pendidikan ( Studi Di SDN 44 Mande Kota Bima ). 7(2), 93-107.

Bao, W. (2020). COVID-19 And Online Teaching In Higher Education : A Case Study Of Peking University. March, 113-115. Https://Doi.Org/10.1002/Hbe2.191

Dedy Achmad Kurniadi, Linda Setiawati, S. N. (2014). Manajemen Pembiayaan Pendidikan Terhadap Mutu Sekolah Menengah Kejuruan. 263-269.

Goldschmidt, K., \& Msn, P. D. (2020). The COVID-19 Pandemic: Technology Use To Support The Wellbeing Of Children. Journal Of Pediatric Nursing, 53, 88-90. Https://Doi.Org/10.1016/J.Pedn.2020.04.013

Gunawan, N. M. Y. S., \& Fathoroni. (2020). Variations Of Models And Learning Platforms For Prospective Teachers During The COVID-19 Pandemic Period. Indonesian Journal Of Teacher Education, 1(2), 6170 .

Juknis_BOP_RA_Dan_BOS_Madrasah_20020.Pdf. (N.D.).

Kusuma, J. W. (N.D.). Platform Whatsapp Group Dan Webinar Zoom Dalam Pembelajaran Jarak Jauh Pada Masa Pandemik Covid 19 Universitas Bina Bangsa , Serang

Mannuhung, S. (2020). Efektivitas Pendayagunaan Biaya Bantuan Operasional Sekolah Dalam Anggaran Kualitas Pendidikan Sekolah Dasar Swasta Dan Negeri. 6(1), 78-86.

Maria, R., \& Padang, U. N. (2021). Edukatif: Jurnal Ilmu Pendidikan Efektivitas Penggunaan Dana BOS Di Madrasah Tsanawiyah Negeri. 3(4), 1602-1611.

Munir, A. (2013). Dalam Perspektif Islam. 8(2).

Pendidikan, J. A., Universitas, P., Kuala, S., Andi, M., \& Usman, N. (2015). Swasta Di Kabupaten Pidie. 3(4), $53-63$.

Sari, H. P. (2020). Menteri Agama Anulir Pemotongan Dana BOS Madrasah Dan Ponpes Setelah Diprotes Komisi VIII DPR. Kompas.Com.

Soewartoyo. (2007). Dasar-Dasar Organisasi Dan Manajemen. Ghalia Indonesia.

Stenger, M. (2013). What Makes A School Successful? The Five Factor Theory Of Effective Schools. Open Colleges.

Sun, L., Tang, Y., \& Zuo, W. (2020). Coronavirus Pushes Education Online. Nature Materials, 19(June), 2020. Https://Doi.Org/10.1038/S41563-020-0678-8

Verawardina, U., Asnur, L., Lubis, A. L., \& Hendriyani, Y. (2020). Reviewing Online Learning Facing Thecovid-19 Outbreak. 